Ádám HORVÁTH

Balázs GYENGE

Georgina RÁCZ

\title{
3.5. ENTERTAINMENT OF YOUNG GENERATION: MOVIE VIEWING HABITS
}

\begin{abstract}
Summary
Authors aim to analyse a pilot study that was conducted with university students regarding their movie viewing habits, focusing on the various influences and sources of information that have an effect on their choices concerning both the methods of viewing movies and the selection of certain movies as well. Among its main results is the general disregard to traditionally highly regarded influences like movie awards or information aggregation websites (such as the Internet Movie Database for example), the overwhelming dominance of piracy when it comes to current movie viewing trends and some of the main expectations concerning legal movie streaming services (which could turn them into viable alternative options).
\end{abstract}

Keywords: consumer behaviour, culture, movie consumption

\section{Introduction}

Universities play a very important role in every society, while their enrolled students appear as an accessible and large population, which could be considered appropriate subjects to study. Furthermore, they are a target market that watches a great amount of movies each year according to SMRB data (young people generally tend to be more frequent moviegoers, as MPAA statistics show the 18-24 and 25-39 are the two largest frequent-moviegoing age groups, representing $31 \%$ of the US population). Movie theatres and "home cinema" generally play a large part in the life of university students as previous studies that aimed to divide their free time showed (Ságvári, 2009). Unlike the 80 's, where it was generally close to imaginable that university students would watch movies that were made for general masses - as opposed to art films -, they prefer larger multi screen movie theatres to smaller art cinemas (Varga, 2005). On another note, we could say that we live in the new age of digital multimedia where movie distribution is facing major changes as well as the general methods of how the customers garner information (or try to measure the value of a certain title), especially when it comes to the internet (Deák, 2008). While the greatest challenge of the industry is often perceived to be piracy, a lot more could be gained if the focus shifted to accommodate the changing demands and to try and offer competitive alternatives instead, especially so as by the time university students graduate, they already represent a significant buying power and reaching them in time may lead to decades of loyal customers. 
Horváth, Á. - Gyenge, B. - Rácz, G.

The aims of the study are to provide a brief overview of some factors that affect consumer behaviours concerning movies, which is followed by the results where the main influential information sources and indoor/outdoor movie related choices are examined.

\section{Factors affecting consumer purchases}

\subsection{Defining changes of technology}

As we witnessed the slow regression of art cinemas and the decline in viewership of multi-screen movie theatres (when it comes to yearly grosses, the Hungarian movie theatres eventually recovered, though it is not an easy task to keep track as three years of data is missing from the statistical records (Nemzeti Média- és Hírközlési Hatóság, 2015)), which was empowered by the slow shift of scenery, as more and more people started to watch movies from the comfort of their homes. As for home cinema, the greatest change came in the form of the digital revolution, beginning with the lightning-fast spread of the DVD (Lobenwein and Pápai, 2000), which represented a vast improvement over the aging VHS, with a more resistant build and a superior storage capacity which resulted in higher quality versions of movies concerning both sound and picture as well as the inclusion of previously absent extra features (such as adding audio and subtitle tracks for numerous languages and audio commentaries made by the filmmakers as well as several types of various extra content like the collection of deleted scenes etc.). The second phase of the digital revolution came a bit later on with the widespread of - the practically limitless - broadband internet connection. Data from 2014 show $74 \%$ of the population of Hungary as internet users, while the whole of Europe has an internet penetration of 70,5\% (Internet World Stats, 2014). With the rise of the continuously improving video and audio compression methods, both the illegal and legal ways of internet distributed movies gained a lot, which resulted in offering better quality with smaller file sizes to download or to instantly watch with video streaming technology (Apostolopoulos et al., 2002), which made the process of watching movies at home even more effortless.

\subsection{Group dynamics and attitude}

Consumer behaviour is greatly affected by their immediate environment, especially those groups that one is, or would like to be a member of (Hofmeister-Tóth, 2006). The need to identify with a group may have an influence similar to the classical choices of products or brands in the case of choosing a certain movie to watch as well. Sorting by the extent of influence coming from the group (Bearden and Etzel, 1982), movie watching can be placed in both the visible and the invisible (or hidden) consumption groups. This means that depending on whether a consumer watches a movie alone or does it with his/her acquaintances, entirely different factors may predominate in the accompanying choices: while they might prefer a certain genre and type of movie when they are together with a given group, they might prefer something completely different when they are browsing movie titles in their home, alone. Group 
influence is also an important factor in the prominent method of watching movies as well. The general worth of watching a movie to a reference group - that acts like a sort of identification point - helps to decide whether to watch a new title in a movie theatre or wait for the home release. It may also determine that the primary acquisition method of a movie is a purchase or an illegal download (under the idea that a movie does not represent enough worth to deserve actual money to be spent on).

Based on the above and the fundaments of opinion leadership, there are websites that offer a service based on their huge aggregated user database (which in this case appears as a sort of really large group with a huge number of members), where - with the aid of a complex algorithm that takes all of the movie related data into account (like the various user reviews, genre classifications, the various keywords or even extra information that may be gathered from the users social network) - they are relatively accurately able to determine that given a certain user likes a particular movie, which other titles should be recommended based on that (and the aforementioned) information (He and Chu, 2010).

While attitudes are known to have a direct influence on our behaviour, the ability to react on these attitudes should be highlighted as well. Even with a positive attitude towards a movie, the individual's financial status or simply the movie's availability (as it might be disregarded by local distributors) could deny the purchase of it. In these instances the only option left for the consumer is to download it from the internet (which might appear in a specifically high number of suppletory downloads (Bodó and Lakatos, 2009)).

\subsection{Online black market and piracy}

In parallel with the aforementioned spread of broadband internet connection in Hungary, the traffic of download sites is growing as well. In the past couple of years the Hungarian torrent sites' user base has been constantly growing (though thanks to their private nature, the pacing is quite slow). University students especially are getting largely accustomed to file sharing, ultimately becoming more choosier consumers in the process, as they are more likely to base their value calculations and purchases around the availability of free content and previewing media via file sharing (Jones, 2002). It is clear that in the past years not paying and illegally downloading or using other free sources (as it may be observed in the proliferation of ad-supported websites offering movies among other content for completely free) instead has become the standard mean of obtaining movies, as one of the leading reasoning behind piracy is the phrase "everyone is doing it", while the physical aspect of actually owning content is no longer considered a motivator (Bothun and Lieberman, 2010).

All the while, as a previous study has pointed it out, free access to content raises the interest in cultural products, ultimately widening the industry (Oberholzer-Gee and Strumpf, 2009). Adapting to the modern culture consumption trends proves to be quite a challenging task for media industries. Currently the main idea to resolve the issue still seems to be to minimize losses (a good example would be Disney's recent halt to release Blu-ray editions in the Hungarian region) and to fight an unwinnable battle against the pirates (where even after a long and tiresome court case and the removal of 
Horváth, Á. - Gyenge, B. - Rácz, G.

the targeted pirate site, another three will instantly fill the void it leaves behind). The challenge, however, is not unreasonable as there are multiple positive examples (like the music or gaming industry) already up and running with methods that could aid to turn the phenomenon into an advantage, by providing competitive alternates to the illegal downloads. This is where the various forms of legal online movie distribution systems could enter the picture, which however still have to overcome many obstacles ahead of them. Among these it should be highlighted that in many cases, the legal downloads' price tags are completely identical to movies that are sold in ordinary brick and mortar stores, even though the physical data carrier (together with all of the cost associated to their production) is removed from the equation (Bodó and Lakatos, 2009).

\section{Material and methods}

The quantitative research of the pilot study was conducted with the aid of questionnaires. The survey instrument took between five to ten minutes to complete, contained only closed questions, grouped into five sections, covering the respondents' movie viewing frequency, information gathering methods, movie viewing habits, attitudes and demographics.

The target group was made of movie consuming university students recruited at Szent István University, during the fall semester of 2014. The questionnaires were filled out by 112 respondents, which after the data cleansing resulted in a sample of 108 . The sample consisted of $67,5 \%$ males and $32,4 \%$ females; $9,26 \%$ of the respondents were younger than 20, while the majority was between ages of 20 and 24 with $65,74 \%$, while the rest of the respondents (categories of people aged 25 and above) were $25 \%$. For the analysis IBM's SPSS software was used. It should be noted that because of the method and size of sampling, the study should not be considered representative.

\section{Results and discussion}

When it comes to watching movies in movie theatres, most respondents answered that they go with their friends and significant others $(73 \%$ and $56 \%$, respectively chose these options, in a question where they were allowed to choose multiple answers), while only a negligible ratio of people go alone (only 10\%). These support the notion that this particular method represents some kind of community experience, or an "event", where having one's friends for the ride adds another element to the already unique feel of the movie theatre.

On the subject of movie theatres another aspect was how satisfied the respondents were with the pricing of movie tickets. The answers on the statement "I am fully satisfied with the movie ticket pricing" (on a 1 to 5 scaling, where 5 meant that they completely agree with said statement), the mean value was 2,72 with a std. deviation of 1,05 (with the majority of respondents checking the options $2(26,9 \%), 3(33,3 \%)$, and $4(22,2 \%)$, with a variation coefficient of 0,39$)$. This result while does not justify to state that that they are not satisfied with the current prices, it does show that they are 
rather tending more for the middle ground and are actually just accepting the current pricing, they "settle" for it.

Moving on to information gathering, the participants were asked what sources of information they most commonly use to search for movies (they were allowed to mark multiple answers). The exact results can be seen in Figure 1.

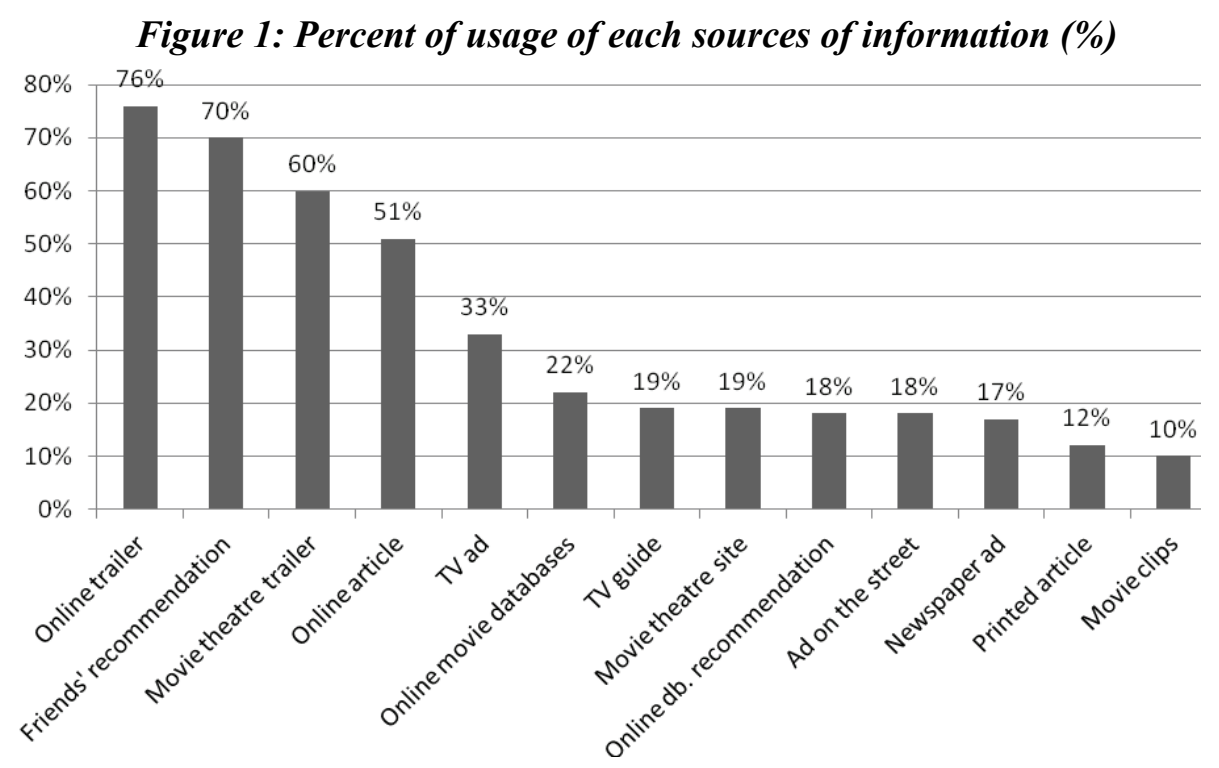

Source: Own elaboration based on the responses of the participants

While some traditionally highly regarded options like online movie databases (i.e. $\mathrm{IMDb}$ and the likes) and their recommendations were mostly neglected, the most popular choices were the online movie trailers (which represents how important the internet is, as movie trailers are basically just a few clicks away for everyone) and the recommendation of friends (representing the importance of group dynamics and opinion leaders). To expand on the latter, the respondents were asked, how likely it is that they recommend a movie they liked to their friends, which got the mean value of 4,56 (with a std. deviation of 0,66 ), highlighting the importance of word-of-mouth marketing (it should be noted however that the respondents were somewhat more reluctant to share their ill experiences, which got a mean value of 3,82 with a 1,15 std. deviation). As a semi-related subject, the respondents were also asked how they feel about movie awards (another generally highly regarded measures of quality). The results came in somewhat shocking, as the participants showed quite low interest in them, the statement about checking the list of awarded movies after the ceremony got a mean value of 2,29 with a std. deviation of 1,37 (with the majority of respondents checking the option to never actually do that with $43,5 \%$ checking option 1 , with a variation coefficient of 0,6 ), while the one about looking up if a certain movie got any awards before watching them got a mean value of 1,88 with a std. deviation of 1,08 (again, with the majority of respondents checking the option to never actually do that with $49 \%$ checking option 1 , with a variation coefficient of 0,58 ), which all in all 
implies that movie awards in general are not a defining factors in the evaluation of movies.

When it came to the act of watching movies at home, the respondents had to treat all of their movie watching (conducted in their homes) as 100\%, then divide that among the various methods of doing so, the exact results are shown in Figure 2.

\section{Figure 2: Repartition of home cinema (\%)}

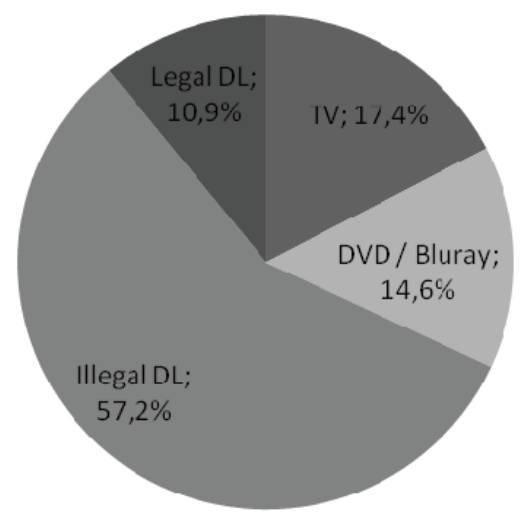

Source: Own elaboration based on the responses of the participants

The results show that home cinema is mostly $(57,2 \%)$ done by pirated versions of movies, which based on previous experiences did not come as a surprise. Seemingly the ever-accessible free content is far ahead of both the "free" television-aired movies (that are continuously interrupted with ad breaks and are not necessarily aired in the right time slot for everyone) and the purchased (be it online or in a brick and mortar store) ones.

If however they were to switch to a system of legal downloading (or streaming), the most desired features would be the high quality of sound and picture (with a $88 \%$ of respondents marking this answer in a question with multiple possible answers) with comfortable and practical usability at close second (78\%). This result showcases the high standards that they have gotten used to with pirated contents (as evidenced by the eviction of poor quality CAM recordings and the like from most pirate sites), though there is still room to improve for legal methods with the ease of use appearing as a possible huge advantage to pirates (where it is quite troublesome to find the right versions to watch, with possibly spending even more time to find the matching subtitles in case no dubbed audio tracks are available).

\section{Conclusion}

When it comes to the selection of movies, the main information source is the internet, primarily in the form of online movie trailers. The search for these is practically the first step that follows hearing about a new title, be it a news article from some movie related website or a recommendation that comes from a friend. The latter information source is also decisive in nature, as university students are still greatly influenced by groups and opinion leaders. This is reflected mainly in the continuous information 
exchange between friends (mostly in the form of suggesting positively viewed movies to each other) and that most of them do not visit movie theatres alone. Even though this is a relatively rarer occasion to watching movies in their homes (which however is something they mostly do alone), it is best as a sort of special, event-like activity.

All the while it seems clear that university students are generally not satisfied with the current pricing of movies, though the ticket prices of movie theatres do appear as a general point of reference. In the case of home cinema, however, the high prices and subpar features turned most to illegal downloads (with a special mention to the seemingly free television as another movie viewing platform, which is plagued by the constant disruptions of ad breaks and the strict schedule of TV stations, that may differ from the viewers personal preferences, all in all pointing out that time allocation is a very highly regarded resource as well).

In the case of legal downloads it seems natural to lower the prices of individual movies, as they are missing many costly elements that come from the physical nature of the traditional distribution of movies, like manufacturing, transporting, storing etc. costs (as after purchasing the right for online download, to give access to the content the providers' only concern is the cost of the bandwidth (which gradually rises as they reach for higher revenue)). All the while they should focus more on improving the qualities and accompanying features of their systems, working towards the goal where it truly is "by a click of a button" to watch any movie legally.

Future studies with higher sample sizes should consider more deeply the reasoning behind why university students might still prefer the illegal methods to obtain movies when legal alternatives are presented as well (apart from pricing) and what other not yet implemented and tested features could be desired by them (that could elevate the home cinema services above piracy as it did in other industries). Additionally, to examine the reasons behind their behaviour and view on the general worth of movies, lifestyle and general attitude towards movies (and other forms of related media) should be taken into consideration.

\section{References}

1. Apostolopoulos, J.G.; Tan, W.; Wee, S.J. (2002): Video Streaming: Concepts, Algorithms, and Systems. Streaming Media Systems Group, Hewlett-Packard Laboratories. Retreived from http://people.cs.clemson.edu/ johnmc/courses/cpsc875/HPL-2002-260.pdf (accessed: 2015.08.15)

2. Bearden, W. O.; Etzel, M. J. (1982): Reference Group Influence on Product and Brand Purchase Decisions. Journal of Consumer Research, Vol. 9 No. 2, p. 183-94. Retrieved from https://www2.bc.edu/ woodsiar/nov\%202\%20reference\%20grp.pdf (accessed: 2015.04.10) http://dx.doi.org/10.1086/208911

3. Bodó, B.; Lakatos, Z. (2009): A filmek online feketepiaca és a moziforgalmazás. Szociológiai Szemle, Vol. 21 No. 2, p. 111-140. Retrieved from http://www.szociologia.hu/dynamic/szocszemle_2011_2_111_140_bodo_lakatos.pdf (accessed: 2015.04.10)

4. Bothun, D.; Lieberman, M. (2010): Discovering behaviors and attitudes related to pirating content. PwC Consumer intelligence series. Retrieved from 
Horváth, Á. - Gyenge, B. - Rácz, G.

https://www.pwc.com/us/en/industry/entertainment-media/assets/piracy-survey-summaryreport-0111.pdf (accessed: 2015.08.17)

5. Deák, D. (2008): A világháló Lumière-jei. Filmvilág Vol. 51 No. 1, p. 44-45.

6. He, J.; Chu, W. W. (2010): A Social Network-Based Recommender System (SNRS). Annals of Information Systems Vol. 12, p. 47-74. Retrieved from http://www.cobase.cs.ucla.edu/tech-docs/jmhek/snrs.pdf $\quad$ (accessed 2015.08.15) http://dx.doi.org/10.1007/978-1-4419-6287-4_4

7. Hofmeister-Tóth, Á. (2006): Fogyasztói magatartás. Aula Kiadó, Budapest, p. 90-111.

8. Internet World Stats (2014): Internet Stats and Facebook Usage in Europe 2014 Mid-Year Statistics. Retrieved from http://www.internetworldstats.com/stats4.htm (accessed: 2015.01.06)

9. Jones, S. (2002): The Internet Goes to College: How students are living in the future with today's technology. Pew Internet \& American Life Project

10. Lobenwein, D.; Pápai, Zs. (2000): Digitális forradalom. Filmvilág, Vol. 43, No.2, pp. 45-46.

11. Nemzet Média- és Hírközlési Hatóság Nemzeti Filmiroda (2015): Mozgóképszakmai statisztika. Retrived from http://nmhh.hu/tart/index/1466/Statisztika (accessed: 2015.04.12)

12. Ságvári, B. (2009): Fanta TrendRiport VI.: „Múzsák vonzásában” Kultúra- a mediafogyasztási szokások a fiatalok körében. Retrieved from http://campuslet.unideb.hu/dokumentumok/tanulmanyok1/fantatrendriport6_09102606265 1.pdf (accessed: 2015.04.10)

13. Simmons Market Research Bureau (1996). Study of Media and Markets. New York.

14. The Motion Picture Association of America (2015): 2014 Theatrical Market Statistics. MPAA. Retrieved from http://www.mpaa.org/wp-content/uploads/2015/03/MPAATheatrical-Market-Statistics-2014.pdf (accessed: 2015.06.05)

15. Varga, D. (2005): Színház helyett multiplex. Népszabadság, Április 13. pp. 5-6. 